Wawzonek, "The Sex They Really Need" 33

\title{
"The Sex They Really Need": Medicalization and Popular Interpretations of Homosexuality in Postwar Canada
}

Joseph Wawzonek

When discussing the cultural impacts of the Cold War, it has increasingly become a given that homosexual men were persecuted in the United States due to McCarthyism's welldocumented Lavender Scare. ${ }^{1}$ This is by no means a phenomenon that individuals accidentally stumbled into knowing; the purges carried out in the public service were intentionally publicized, effectively state-sanctioning homophobia due to queerness being antithetical to national security.

Contrastingly, the purges that took place in Canada during the same period seem largely erased from national history, despite remaining in living memory for many of those affected. The rationale was effectively identical: a need for secrecy from an Eastern 'other' which necessitated the removal of homosexual men and women from positions of power in both civil and military service. Their sexuality constituted a form of deviancy, thereby making them supposedly vulnerable to blackmail, and in turn a liability that could relinquish state intelligence while also diminishing projections of masculine power.

The Cold War repression of homosexual men and women in Canada did not exist in a vacuum, and was informed by government intelligence, academic research, and public perceptions of those who subverted sexual normalcy and heterosexual hegemony. In this paper, I will be examining two key publications in Canadian medical journals to demonstrate how they informed both popular print media and state constructions of homosexuality from 1950 through to 1969 , the year that homosexuality was decriminalized in Canada. In employing a queer reading of these texts, I argue that postwar gender anxieties served as the primary driving factor for Cold War homophobia and that the construction of homosexuals as weak, sexual criminals was the result of a self-reinforcing cycle of information interpretation between the medical community and the popular press and government.

Considering the close-knit relationship between the United States and Canada during the Cold War raises the question as to why the Lavender Scare and Canadian purges do not share more in common. Though the Lavender Scare pervaded the late 1940s and was in full effect through to the late 1950 s, the Canadian equivalent seems oddly late with a development that began in earnest in 1958 and 1959 as American purges declined. ${ }^{2}$ Certain measures against homosexuals did exist in Canada prior to 1958, including the Immigration Act of 1952 which explicitly forbade "prostitutes, homosexuals or persons living on the avails of prostitution or homosexualism [sic]." ${ }^{3}$ And, the Security Panel, which was central to the homosexual witchhunt, came into existence in 1946, informed by wartime categorization and bureaucratic

\footnotetext{
${ }^{1}$ See David K. Johnson, The Lavender Scare: The Cold War Persecution of Gays and Lesbians in the Federal Government (Chicago: The University of Chicago Press, 2004).

${ }^{2}$ See David K. Johnson, The Lavender Scare: The Cold War Persecution of Gays and Lesbians in the Federal Government (Chicago: The University of Chicago Press, 2004). ${ }^{3}$ An Act Respecting Immigration 1952, c. 42. http://www.canadiana.ca/view/oocihm.9_08041/; Philip Girard, "From Subversion to Liberation: Homosexuals and the Immigration Act 19521977," Canadian Journal of Law and Society 2 (1987); Gary Kinsman, "Official Discourse as Sexual Regulation: The Social Organization of the Sexual Policing of Gay Men" (PhD diss., University of Toronto, 1989), 88-90.
} 
procedures. ${ }^{4}$ As sociologist Gary Kinsman and gender historian Patrizia Gentile argue in The Canadian War on Queers, British investigations into homosexuals as a threat to national security are a key influence for the relative lateness of Canadian equivalencies, especially following the 'homosexualisation' of defectors Guy Burgess and Donald Maclean in 1956. ${ }^{5}$ Furthermore, political scientist Reg Whitaker suggests that the Canadian system of investigating alleged security threats was directly informed on how not to proceed with dismissals or removal of security clearances by American and British precedents as early as $1947 .{ }^{6}$ Suggesting that these cases were to be explained away as being "on grounds of personal unsuitability rather than on grounds of "security'," the Canadian government constructed a system wherein they might avoid the publicization and politicization of national security issues as seen in the US and Britain, theoretically protecting affected individuals from public persecution. ${ }^{7}$

Homosexuality's illegality established a reasonable cause for concern that those with 'deviant' sexuality might be subject to blackmail, but the perceived problem went beyond the law. What initially gave the RCMP's Security Panel pause in 1952 was homosexuality's association with character weakness, as indicated in Cabinet Directive 24, explicitly calling attention to the fact that "'defects' of character [...] might lead an employee to be indiscreet, dishonest or vulnerable to blackmail." ${ }^{8}$ Given the perception of homosexuality as a mental illness akin to alcoholism or schizophrenia, one avenue for understanding the context of the early Cold War period can be discovered in medical journals, such as the Canadian Medical Association Journal (CMAJ).

A thorough search of CMAJ's archival history reveals minimal mention of homosexuality before the Kinsey Report's publication in 1948, shortly after the first purges of the Lavender Scare. Only in September 1950 was a review article for homosexuality even published, Samuel Ralph Laycock's "Homosexuality - A Mental Hygiene Problem." As Dean of Education and Professor of Educational Psychology at the University of Saskatchewan as well as a Director at The Canadian Mental Hygiene Association, it is apparent Laycock was very well educated and would be considered an authority, and the peer-reviewed nature of CMAJ further cemented Laycock's work as a well-informed reflection of medical understandings at the time.

The title's association of homosexuality with mental hygiene has foundations in wartime military conceptions of 'psychopathic personalities' (including homosexual men), wherein they were deemed "unable to meet the usual adult social standards of truthfulness, decency, responsibility, and consideration for their fellow associates. They are emotionally unstable and

${ }^{4}$ An Act Respecting Immigration 1952, c. 42. http://www.canadiana.ca/view/oocihm.9_08041/; Philip Girard, "From Subversion to Liberation: Homosexuals and the Immigration Act 19521977," Canadian Journal of Law and Society 2 (1987): 4; Gary Kinsman, "Official Discourse as Sexual Regulation: The Social Organization of the Sexual Policing of Gay Men” (PhD diss., University of Toronto, 1989), 88-90.

${ }^{5}$ Gary Kinsman and Patrizia Gentile, The Canadian War on Queers (Vancouver: The University of British Columbia Press, 2012), 86-87.

${ }^{6}$ Reg Whitaker, Cold War Canada: The Making of a National Insecurity State, 1945-1957 (Toronto: University of Toronto Press, 1994), 165-166.

${ }^{7}$ Whitaker, Cold War Canada, 166.

${ }^{8}$ Canada. Royal Commission of Inquiry into Certain Activities of the RCMP, vol. 2, p. 782.

9 S.R. Laycock, "Homosexuality - A Mental Hygiene Problem," Canadian Medical Association Journal 63 (September 1950): 245-250. 
absolutely not to be depended upon." ${ }^{10}$ Laycock takes a liberal approach in delineating the problems of deeming homosexuals 'sex perverts', noting that heterosexuals could also be perverted, and that many homosexuals did not act on their desires and were as sociable and industrious as any straight Canadian. ${ }^{11}$

The general public and some medical professionals, he highlights, were under the impression that homosexuals could be discerned by their dress and actions. This line of thinking is adjacent to what Judith Butler refers to as gender performativity, with gay men adopting and reiterating societal constructions of the feminine (high-pitched voice, creative sensibilities, lack of emotional balance, feminine clothing), and the inverse for lesbians. ${ }^{12}$ Such notions were not unique to Canada, as the Minnesota Multiphasic Personality Inventory (MMPI), first used in 1943, was contemporaneously associating attributes such as an identification with singers or even simply exhibiting empathy as feminine characteristics. ${ }^{13}$

The MMPI's Masculinity/Femininity tests would form the foundation of the infamous Fruit Machine homosexuality tests developed by Frank Robert Wake for the RCMP, a means of allegedly detecting those of deviant sexuality in the Canadian public service. There too would individuals respond to statements by either associating with them or not, again reinforced by contemporary hegemonic masculinities - men aspire to be political leaders, women wish to be librarians. ${ }^{14}$ The assumption in these cases was that homosexuals effectively (and sometimes literally) transvested themselves into part of a gender order in which it was proper to have those of the same sex as objects of desire. In dismantling this assumption and advising that "caution must, therefore, be exercised in picking out homosexuals by appearance and manner alone," Laycock demonstrates one of the key issues for authority during the homosexual purges: identifying gay men and lesbians without superficial markers of their sexuality, especially as any alleged signs of one's orientation might denote different gender or sexual expressions depending on their race, as the MMPI showed in its conflation of black masculinity and white femininity. ${ }^{15}$ The symptoms were not public, and the causes were societal rather than physiological.

Contemporaneous views of homosexuality labelled the mother's role in one's upbringing as a leading cause of sexual inversion. To claim that boys became gay through maternal associations that materialized as disdain for women as objects of desire or reverence which made the female objet petit a (as all women become identified with the mother with whom sex is forbidden), Laycock conjures the spectre of momism, a theory borne of gender anxiety by Philip

${ }^{10}$ Daniel J. Robinson and David Kimmel, "The Queer Career of Homosexual Security Vetting in Cold War Canada," The Canadian Historical Review 75, no. 3 (September 1994): 333.

${ }^{11}$ Laycock, "Homosexuality," 245-246.

12 See Judith Butler, Gender Trouble (New York: Routledge, 2007), 185-190; Laycock, "Homosexuality," 246-247; Elise Chenier, Strangers in Our Midst: Sexual Deviancy in Postwar Ontario (Toronto: University of Toronto Press, 2008), 91.

${ }^{13}$ Audio reel recording, Family Life Education: A Community Responsibility: A Symposium on Sex Education for those Involved in any aspect of Education or Counselling, Toronto, 23

September 1967, F0098-S0006-FL0100, Box 113, Folder 2, C. Bruce Hatfield fonds, University of Calgary Archives, Calgary, Alberta, Canada.

${ }^{14}$ Kinsman and Gentile, The Canadian War on Queers, 177.

${ }^{15}$ Laycock, "Homosexuality," 247; Family Life Education: A Community Responsibility, 23 September 1967. 
Wylie in his 1942 book Generation of Vipers. ${ }^{16}$ Considering the alleged "sexual and emotional immaturity" of homosexuals, it is clear the problem is not one's sex object, but what that sex object represents - in this case, a stunted mental state which could be corrected through counselling to reach a 'heterosexual maturity'. ${ }^{17}$ For homosexual men especially, their appropriation of femininity came with the caveat of espousing negative aspects of the hegemonic feminine as well, namely physical, moral, and mental weakness, passivity, and a desire for compromise, all traits that would be championed by the RCMP as making gay men less able to resist Communist rhetoric. ${ }^{18}$

Informed by both medical rationale and information gleaned from Canada's allies, the RCMP Security Panel came to understand that "Communist intelligence services were relying upon the exploitation of the vulnerabilities of individuals rather than their ideological principles," necessitating a means of determining sexuality in lieu of obvious signifiers. ${ }^{19}$ The purges began in the belief that homosexuals were already being blackmailed by Soviet intelligence agencies in the late 1950s and were capitulating to them, but at the same time, internal Security Panel memos highlighted that there were no cases of homosexuals committing treason under threat of blackmail by $1958 .{ }^{20}$ Indeed, as investigative journalist John Sawatsky argues, early dismissals of homosexuals employed by the government had nothing to do with loyalty or honesty at all, rather they were made to resign out of fears of reprisals like those in the States in the wake of McCarthyism. ${ }^{21}$ As explained in Sarah Fodey's documentary The Fruit Machine, many affected individuals were coerced into resigning, often being handed the necessary paperwork to do so. ${ }^{22}$ Operating on rumours and fear rather than reality, in 1959 the RCMP began investigating homosexual men and women in earnest throughout the Canadian government, not on grounds of unsuitability or disloyalty, but as intrinsic security risks.

Barbara Moon's article "Defining the Sex Offender" in April 10, 1965's edition of The Globe and Mail shows a popular press application of the sort of thought presented by Laycock almost fifteen years earlier, backed by consultation of doctors at the Forensic Clinic, J.W. Mohr and R.E. Turner. Moon is quick to discount conflations of homosexuals with the likes of other 'sexual deviants' such as child molesters and exhibitionists. As Section 158 of the Criminal Code grouped varying types of sexual crimes, Moon notes that the charge of indecent behaviour could be lobbied against "the drunk relieving himself in an alleyway" as easily as it could be against "a

\footnotetext{
${ }^{16}$ Roel van den Oever, Mama's Boy: Momism and Homophobia in Postwar American Culture (New York: Palgrave MacMillan, 2012), 5, 20. Laycock, "Homosexuality," 247-248.

${ }^{17}$ Laycock, "Homosexuality," 248.

${ }^{18}$ Erin Gallagher-Cohoon, "Illegal Loves and Sexual Deviancy: Homosexuality as a Threat in Cold War Canada," Constellations 4, no. 2 (2013): 362.

${ }^{19}$ Robinson and Kimmel, "The Queer Career," 331; Royal Commission of Inquiry into Certain Activities of the RCMP, vol. 2, p. 782

${ }^{20}$ Kinsman and Gentile, The Canadian War on Queers, 92.

${ }^{21}$ John Sawatsky, Men in the Shadows: The RCMP Security Service (Toronto: Doubleday Canada Limited, 1980), 124-125.

${ }^{22}$ The Fruit Machine (Feature Version), directed by Sarah Fodey (2018; Toronto, ON: TVOntario), Streaming Video, 00:12:14.
} 
clinically recognizable exhibitionist," leading to a situation in which "child molesters [were] charged as exhibitionists and exhibitionists as homosexuals."23

There is an understanding in Moon's eyes that the lack of delineation in the Criminal Code is resultant of a lack of research into the psychiatric elements of sexual deviation, something which was already being remedied by the Forensic Clinic; their patients were largely homosexuals, pedophiles, and exhibitionists but the categories were not collapsed as was being done by other sexologists and the law. ${ }^{24}$ This association of homosexual men and pedophilia, as Kinsman argues, had its origins in the British Wolfenden Report published in 1957 which deemed the homosexual male a "menace to boys," and homosexuality used as a label for both men seeking adult men as sexual partners and "men who seek as partners boys who have not reached puberty." 25 The majority of Moon's discussion focuses on exhibitionists and pedophiles, and the development of means of diagnosing these individuals from the charges laid against them by police to better categorize those tried under Section $158 .{ }^{26}$ Certainly, distinguishing between homosexuality and those committing pedophilic acts or bestiality was progressive for its time and that sympathetic attitude made the Forensic Clinic effective allies of the homosexual movements and communities in Canada. ${ }^{27}$

Though homosexuality is not at the heart of Moon's discussion, it can be inferred then that this goal of diagnosis would have pervaded into Mohr and Turner's treatment and analysis of gay men and lesbians. Their reiteration of momism can thus be construed as a result of seeking an underlying common cause for identifying homosexuals so they may be tried and understood as such, rather than being considered one of the other types of 'deviants' within Section 158. Indeed, momism is briefly alluded to in a quote from a senior psychologist at the Forensic Clinic Dan Paitich, stating "if it's possible to make one large generalization about deviates, it's this: their relations with their fathers determine whether they will be deviates; the relations with their mothers determine what sort they'll be," once more shifting the blame onto parental failure. $^{28}$

Renate Wilson's “What Turns Women to Lesbianism?” in Chatelaine's October 1966 issue represents something of a turning point in the consideration of the lesbian in Canada. What is evident from the sources discussed so far is the minimization of lesbian experiences in Canada; they were subject to the same purges from public service as gay men (though not in as large numbers) and yet they are effectively a non-factor as far as the medical community and popular press are concerned. The public invisibility of lesbians was even stated in Kinsey's Sexual Behaviour in the Human Female, attributing the lack of public concern to religious

${ }^{23}$ Barbara Moon, "Defining the SEX OFFENDER," The Globe and Mail, April 10, 1965, ProQuest Historical Newspapers: The Globe and Mail.

${ }^{24}$ Chenier, Strangers in Our Midst, 127.

${ }^{25}$ Gary Kinsman, The Regulation of Desire: Homo and Hetero Sexualities, 2nd ed. (Montreal: Black Rose Books, 1996), 217.

${ }^{26}$ Moon, "Defining the SEX OFFENDER."

${ }^{27}$ Chenier, Strangers in Our Midst, 130.

${ }^{28}$ Moon, "Defining the SEX OFFENDER;" Kathryn Campbell, "'Deviance, Inversion and Unnatural Love:" Lesbians in Canadian Media, 1950-1970," Atlantis 23, no. 1 (Fall/Winter 1998): 132. 
sanctions, "social taboos against anal sex; public ignorance of lesbian sexual practices; [...] and their finding that many men found the idea of lesbianism arousing." 29

Another factor in the erasure of lesbians is the legal context of homosexuality in Canada, which Wilson brings attention to, with Canadian Common Law being derived from English Common Law. English Common Law omits lesbianism as a possibility, as an 1885 revision of legal code "condemned homosexual practices by men and women, [but] Queen Victoria refused to sign it because, as she huffily explained, 'women can't do that together.' Rather than enlighten Her Majesty, her ministers removed women from the clause." ${ }^{30}$ The erasure of lesbians was linguistic as well, pervading to such an extent that one of the twelve gay women Wilson interviews states outright "until I was twenty I didn't even know the word lesbian," creating a deeper othering of the homosexual woman wherein they might realize they are acting against hegemonic heterosexuality without even having the language with which to identify themselves. ${ }^{31}$

Shifted tides in medical thought can be seen in Mohr and Turner's 1967 review article for Applied Therapeutics, titled "Sexual Deviations Part II - Homosexuality." A senior research associate and clinic director respectively at the Outpatient Forensic Clinic of the Toronto Psychiatric Hospital, Mohr and Turner had been at the forefront of forensic sexology and the treatment of sexual deviation and sexual crime. ${ }^{32}$ In their review, they reiterate concepts of momism as a contributing factor in the development of homosexualities in stating "a rather consistent picture emerges, in short, that of a dominating, close-binding mother and a weak, emotionally ineffectual if not negative father," but they just as quickly establish a failure of the momism hypothesis: these ideations of mother and father "came from homosexual patients themselves and [denoted] their relationship to their parents rather than an objective picture of the parents as such." ${ }^{33}$ What is especially remarkable about Mohr and Turner's work is a recognition that homosexuality is not a problem intrinsically, but a problem because of societal contexts. The duo still presents a viewpoint that considered homosexuality 'fixable' in the same way a condition like heart disease can be actively treated. However, this runs counter to the psychiatric consensus through the 1960s, as the likes of Sigmund Freud and Charles Socarides presented homosexuality as a pathological disorder, imposing their cultural and societal beliefs onto their patients. ${ }^{34}$ Mohr and Turner's suggestion was to only treat those who desire treatment as a means of fitting in better with a heteronormative society, and ultimately sought to "achieve the goals they set, not goals set by the staff," demonstrating a permissive if not tolerant approach to homosexuality which may have considered gay men and lesbians to be tragic figures, but certainly not dangerous ones. ${ }^{35}$

Wilson's discussion with her lesbian informants, as well as with Mohr and Turner, constructs an image of lesbianism that would necessarily be more hidden from the public gaze.

${ }^{29}$ Campbell, "Deviance, Inversion and Unnatural Love," 130.

${ }^{30}$ Renate Wilson, "What Turns Women to Lesbianism?," Chatelaine, October 1966, Series 5, Folder 34, C. Bruce Hatfield fonds, University of Calgary Archives, Calgary, Alberta, Canada.

${ }^{31}$ Wilson, "What Turns Women."

${ }^{32}$ Chenier, Strangers in Our Midst, 126-127.

33 J.W. Mohr \& R.E. Turner, "Sexual Deviations Part II - Homosexuality," Applied Therapeutics 9, no. 2 (February 1967): 167.

${ }^{34}$ Robinson and Kimmel, "The Queer Career," 331, 337-338.

${ }^{35}$ Chenier, Strangers in Our Midst, 129. 
According to Mohr, male homosexuals carried out strings of one-night stands, but lesbians sought long-term relationships that emphasized emotionally-supporting elements over sex acts. ${ }^{36}$ During and following World War Two, women commonly lived together as roommates, which historians Alan Bérubé and Donna Penn argue made life for lesbians easier as the pervasiveness of female cohabitation would have prevented suspicion and granted them private space for sexual activity as needed, whereas men would often need to enter public spaces to partake in same-sex acts. ${ }^{37}$ As has been established as a pattern, Wilson blames the homosexualisation of Canadian men on the mother's dominance in a familial hierarchy. Interestingly, she makes not only the ineffectual father complicit in the creation of homosexual boys, but the dominant father responsible for the creation of lesbian girls. As lesbians were categorized as either femme or butch - the former more passive and feminine, the latter more active and masculine - there is presented a possibility that a father's masculinity could reflect on their daughter if their relationship is too close-knit. ${ }^{38}$ Wilson doesn't draw a line similar to Laycock and Wylie wherein the father thereby becomes an unattainable object of sexual desire and all men become associated with the father, rather women 'turned' to lesbianism in this sense are actively competing with their fathers for the love of the mother.

The anxieties concerning the new teenage demographic are also shown with the claim that "most researchers" - not directly quoted or sourced - "interviewed agree that there is possibly an element of teenage rebellion in lesbianism, too - rejection of what's expected." 39 Just as rebellious baby boomers engaged in delinquency and non-traditional sex acts in heterosexual ways, one wishing to be a non-conformist might seek same-sex relationships purely to subvert expectations, thereby mimicking notions of gender inversion which were already largely disproven by the medical community by this time. Ultimately the Chatelaine piece portrays an image of homosexual men and women as “abnormal," even with Wilson's attempts at presenting a more level-headed image by quoting the Wolfenden Report's claims that sexual deviation would not threaten the moral fibre of society. ${ }^{40}$ The breadth of experts consulted means the progressive notions espoused by those working at the Forensic Clinic are balanced out by more regressive sexological thought, primarily from the United States. For example, Turner suggests that seduction is rarely a cause for one's homosexual identity, especially as boys and girls are often approached sexually or seduced yet remain 'normal', that is to say heterosexual; American etiology adhered more strongly to conservative notions that homosexual 'recruitment' is widespread to the extent that over fifty-percent of lesbians are 'caused' by seduction. ${ }^{41}$

Articles discussing homosexuality became more prevalent in the latter half of the 1960s, reflecting similar trends in the rise of characters in popular media which were coded as homosexual - for example, Norman Bates from 1960's Psycho, T.E. Lawrence in 1962's

\footnotetext{
${ }^{36}$ Campbell, "Deviance, Inversion and Unnatural Love," 128; Wilson, "What Turns Women."

${ }^{37}$ Campbell, "Deviance, Inversion and Unnatural Love," 128; See Alan Bérubé, Coming Out Under Fire: The History of Gay Men and Women in World War Two (New York: Free Press, 1990); Donna Penn, "The Sexualized Woman: The Lesbian, the Prostitute, and the Containment of Female Sexuality in Postwar America," in Not June Cleaver: Women and Gender in Postwar America, 1945-1960, ed. Joanna Meyerowitz (Philadelphia: Temple University Press, 1994).

${ }^{38}$ Wilson, "What Turns Women."

${ }^{39}$ Wilson, "What Turns Women."

${ }^{40}$ Kinsman, The Regulation of Desire, 252; Wilson, "What Turns Women."

${ }^{41}$ Wilson, "What Turns Women."
} 
Lawrence of Arabia, or Wade from 1965's Inside Daisy Clover. In 1967, with the Supreme Court of Canada ruling in the case of Klippert v. The Queen, legal reform concerning homosexuality entered the national spotlight as then Prime Minister Pierre Trudeau remarked that "the state [had] no place in the bedroom of the nation." 42 This came to a head with the introduction of Bill C-150 which proposed changes to the Criminal Code of Canada which would lead to the decriminalization of same-sex acts between consenting adults over the age of twenty-one (the age limit being a remnant of the findings of the Wolfenden Report which led to fears of gay men having sex with adolescents). Then Minister of Justice John Turner described it as "the most important and all-embracing reform of the criminal and penal law ever attempted at one time in this country," viewing the provisions therein as a natural reflection of public opinion on the addressed issues, as evidenced by Trudeau's election victory. ${ }^{43}$ Bill C-150 caused a tremendous uproar from Canada's Conservative and Créditistes parties, and the deliberations dragged the conversation out, by extension ever-increasingly involving the public as a means of gauging popular opinion. ${ }^{44}$

While the government deliberated over the bill, the popular media weighed in on the contentious changes, including Jack Batten's "The Homosexual Life in Canada" article for Saturday Night in September 1969. Presented as a dialogue with a gay friend of the journalist though they are never named nor quoted - the piece gives a rare queer perspective on the legal situation faced by homosexual men and women. Batten's informant paints a picture of the homosexual situation that is frank and grim, noting that the reform would cause little change for many queer people in Canada. Addressed by Batten's friend is an issue still grappled with today, that of the public washroom, as they claim "the cops will still be busting the same queers they go after today - the poor souls who are caught quietly stroking someone else's penis in a public washroom or a park or some other place that's so obvious." 45 As presented, the decriminalization of homosexuality only benefitted those who engaged in consensual same-sex acts in private spaces; as mentioned above, those who had access to said spaces were already out of the law's gaze, making steps towards legalization moot.

The ubiquity of cruising in public washrooms was addressed during the debates around the bill by NDP MP John Gilbert who decried the morality squads' spying in public washrooms as a gross invasion of privacy for those who were not seeking casual sex, and he proposed the

42 Kinsman and Gentile, The Canadian War on Queers, 215.

${ }^{43}$ Canada, Parliament, House of Commons, Debates, 28th Parl., 1st sess., January 23, 1969, p. 4717.

${ }^{44}$ Kinsman, The Regulation of Desire, 269; See Rudy Platiel, "Chiefs Oppose Changes in Homosexual Law," The Globe and Mail, September 7, 1968, ProQuest Historical Newspapers: The Globe and Mail; Morton Rapp, "Homosexuality," The Globe and Mail, September 16, 1968, ProQuest Historical Newspapers: The Globe and Mail; "First Tory Announces Support for Change in Criminal Code on Abortion, Homosexuality," The Globe and Mail, January 28, 1969, ProQuest Historical Newspapers: The Globe and Mail; "Liberals are Immoral, Tory Fells Commons," The Globe and Mail, February 26, 1969, ProQuest Historical Newspapers; "Homosexuals not Encouraged, Turner Says," The Globe and Mail, Apri 18, 1969, ProQuest Historical Newspapers.

45 Jack Batten, “The Homosexual Life in Canada: Will Trudeau's Change in the Law Make Any Difference? An Answer from the Gay World," Saturday Night, September 1969, 29, Series 5, Folder 34, C. Bruce Hatfield fonds, University of Calgary Archives, Calgary, Alberta, Canada. 
enactment of by-laws (as suggested by the Wolfenden Report) to prevent gay loitering. ${ }^{46}$ Not protected under the legislation then were "the innocents $[\ldots]$ the secret queers, the scared ones, the poor slobs who can't bring their homosexuality into the open, the married men who crawl in at night from the suburbs for a taste of the sex they really need - sex from other men," for these individuals could not engage in spaces more safely sanctioned for homosexual activity such as gay bars. ${ }^{47}$ The proposals thereby seem like an attempt at self-aggrandizing on the part of the Liberals and NDP but are read as an absence of change by those it would affect. ${ }^{48}$ Furthermore, while homosexuality might be decriminalized, that did not prevent political figures advocating for the change from thinking of gay men and lesbians as ill; perhaps they would not be in jail, but they would be under a doctor's care because they were still an abnormal other. ${ }^{49}$

The passing of Bill C-150 would not bring an end to the gay purges or homophobia exhibited prior to 1969 and did not even stem discrimination in certain areas of gay Canadian life. Though private, adult homosexuality was passed on to medical and social professionals who might treat or alleviate the pains of being queer in a heteronormative society, the public realm of gay experience remained under the heel of police, the RCMP, and the law. ${ }^{50}$ Though the actions carried out by national institutions were certainly informed by the criminalization of homosexuality, they were by no means dependent on it, and so gay men and lesbians remained potential criminals and security risks. ${ }^{51}$ Additionally, the military and RCMP did not need to adhere to the changes enacted by the bill.

Medical thought by this point was already progressing much more rapidly than Canadian society in terms of the conceptualization of homosexuality, and by 1973 the American Psychiatric Association stopped considering homosexuality to be a mental disorder. While it would be another nine years for the Canadian equivalent to follow suit, progressive psychiatric thought as exhibited by the likes of those at the Forensic Clinic, as well as doctors on the cutting edge of sex education understood long before the 1980s that gayness was just the way some people were. ${ }^{52}$ Yet this did not prevent the law and popular media from taking what bits of medical thought fit their narratives, and building homosexuals to be different from what they were. If the label didn't fit, those in power would make it fit.

${ }^{46}$ Canada, Parliament, House of Commons, Debates, 28th Parl., 1st sess., February 25, 1969, p. 5962; Kinsman, The Regulation of Desire, 272.

${ }^{47}$ Batten, "The Homosexual Life in Canada," 32.

${ }^{48}$ Batten, "The Homosexual Life in Canada," 29.

${ }^{49}$ Kinsman, The Regulation of Desire, 270-272.

${ }^{50}$ Kinsman, The Regulation of Desire, 276-277.

${ }^{51}$ Kinsman and Gentile, The Canadian War on Queers, 221-222.

52 Family Life Education: A Community Responsibility, 23 September 1967. 


\section{Bibliography}

An Act Respecting Immigration, Statutes of Canada 1952. C. 42.

http://www.canadiana.ca/view/oocihm.9_08041/

Campbell, Kathryn. "Deviance, Inversion and Unnatural Love:" Lesbians in Canadian Media, 1950-1970.” Atlantis 23, no. 1 (Fall/Winter 1998): 128-136.

Canada. House of Commons Debates, January 23, 1969.

Canada. Royal Commission of Inquiry into Certain Activities of the RCMP. Vol. 2 Ottawa: Canadian Government Publishing Centre, 1981.

C. Bruce Hatfield Fonds. University of Calgary Archives, Calgary.

Chenier, Elise Rose. Strangers in Our Midst: Sexual Deviancy in Postwar Ontario. Toronto: University of Toronto Press, 2008.

Gallagher-Cohoon, Erin. "Illegal Loves and Sexual Deviancy: Homosexuality as a Threat in Cold War Canada." Constellations 4, no. 2 (2013): 359-369.

Girard, Philip. "From Subversion to Liberation: Homosexuals and the Immigration Act 19521977." Canadian Journal of Law and Society 2 (1987): 1-28.

Johnson, David K. The Lavender Scare: The Cold War Persecution of Gays and Lesbians in the Federal Government. Chicago: The University of Chicago Press, 2004.

Kinsman, Gary. Official Discourse as Sexual Regulation: The Social Organization of the Sexual Policing of Gay Men. PhD diss., University of Toronto, 1989.

Kinsman, Gary. The Regulation of Desire: Homo and Hetero Sexualities. Montreal: Black Rose Books, 1996.

Kinsman, Gary and Patrizia Gentile. The Canadian War on Queers. Vancouver: The University of British Columbia Press, 2012.

Laycock, S.R. "Homosexuality - A Mental Hygiene Problem." Canadian Medical Association Journal 63 (September 1950): 245-250.

Mohr, J.W. and R.E. Turner. "Sexual Deviations Part II - Homosexuality." Applied Therapeutics 9, no. 2 (February 1967): 165-168.

Moon, Barbara. "Defining the SEX OFFENDER.” The Globe and Mail (April 10, 1965).

Van den Oever, Roel. Mama's Boy: Momism and Homophobia in Postwar American Culture. New York: Palgrave MacMillan, 2012.

Robinson, Daniel and David Kimmel. "The Queer Career of Homosexual Security Vetting in Cold War Canada." Canadian Historical Review 75, no. 3 (September 1994): 319-345. 
Sawatsky, John. Men in the Shadows: The RCMP Security Service. Toronto: Doubleday Canada Limited, 1980.

The Fruit Machine. Directed by Sarah Fodey. Toronto, ON: TVOntario, 2018.

Whitaker, Reginald. Cold War Canada: The Making of a National Insecurity State, 1945-1957. Toronto: University of Toronto Press, 1994. 